\title{
CONSTRUCTION, MAINTENANCE AND COST OF OVERHEAD CONTACT SYSTEMS
}

\author{
PART II-CATENARY CONSTRUCTION
}

\author{
BY F. ZOGBAUM
}

\begin{abstract}
Paper
This paper is designed to give a general review of the problems involved in the maintenance and the cost of an overhead contact system of the catenary type, carrying high-voltage propulsion currents. The paper includes not only the contact system itself, but the transmission lines which form an integral part of the same. The subject treated is the catenary construction on the New York, Westchester \& Boston Railway, which is purely an electrical line, having no steam whatever. Several points will be brought out, such as the method of maintenance, the organization of the maintenance forces, the efficiency of insulation and other points which may be used in comparison and in discussion.
\end{abstract}

$\mathrm{O}^{\mathrm{N}}$

$\mathrm{NE}$ OF the most important matters pertaining to the maintenance of an overhead catenary system is the inspection of the contact wires and the transmission system, in order that possible failures may be forestalled, so that defects may be discovered and failures prevented. During such an inspection it is important always to note the condition of the contact wire with reference to its position to the track, and at all times to keep the wire as near the center of the track as possible.

Although on some other roads it has been found advisable to stagger the contact wire in order to get the maximum wear on pantagraph shoes, it will be seen from figures that are presented here, that it has not been found necessary in the case of this system to stagger the contact wire to the advantage of pantagraph shoe wear. In noting the position of the contact wire with reference to the track it is essential always to allow for the swaying movement of the locomotive or car carrying the pantagraph. This is especially important on curves, as trains running at high speed on curves of any sharpness over one degree, will naturally swing the pantagraph towards the outside of the 
curve, making it necessary to have the contact wire outside of the center line of the track, whereas on tangents the wire is kept as nearly as possible directly over the center of the track.

The line of the New York, Westchester \& Boston Railway, the catenary system of which is treated herein, consists of 54.26 miles of contact wire and 181.29 miles of transmission lines, which include signal feeders and control line, or 109.17 miles of transmission lines for traction power only. The 54.26 miles of contact wire is suspended over 30 per cent curve track and 70 per cent tangent track, so that practically the only adjustment necessary is on 30 per cent of the road, as the tangent contact wire remains in relatively the same position throughout the year, while the curve contact wire needs slight adjustments from time to time. Included in the catenary system are six sectionalizing or anchor bridges and 77 high-tension oil circuit breakers, which are used for sectionalizing the hightension power. Also, it is considered on this line that the signal transmission lines are included in the electrical distribution or catenary system.

\section{Organization}

The organization for maintenance of the catenary and transmission system is known as the electrical department and includes, not only the maintenance of the contact system, transmission system, signal transmission system, signal transformers and station lighting, and elevator transformers, station elevators and lighting systems, but also takes care of such construction work as may come up from time to time. The electrical department is headed by the engineer of maintenance, to whom the general electrical foreman reports direct. The general electrical foreman has under him, one day foreman and one night foreman, five linemen and one assistant lineman. The day foreman, three linemen and assistant lineman cover the entire system, the majority of the time without special work train, and make repairs on practically all the apparatus as mentioned, except the contact system or parts of the transmission system, which cannot be taken out of service during the day. The night foreman and two linemen cover the entire line and use a work train in inspecting and repairing the contact system. The work train consists of one gasoline-electric locomotive and work car. The gasoline locomotive contains 
the working platform from which repairs are done to the contact system. Erected on the work car is a pantagraph collector, identical with those used on the regular coaches and locomotives. Also on the work car is an electric searchlight, which is used in inspection as well as when making repairs.

\section{Inspection Methods}

During the day time, approximately once each month, the contact system is given a general inspection from the head end

\section{New York, Westchester \& Boston Railway Company \\ Daily Report of Time Worked}

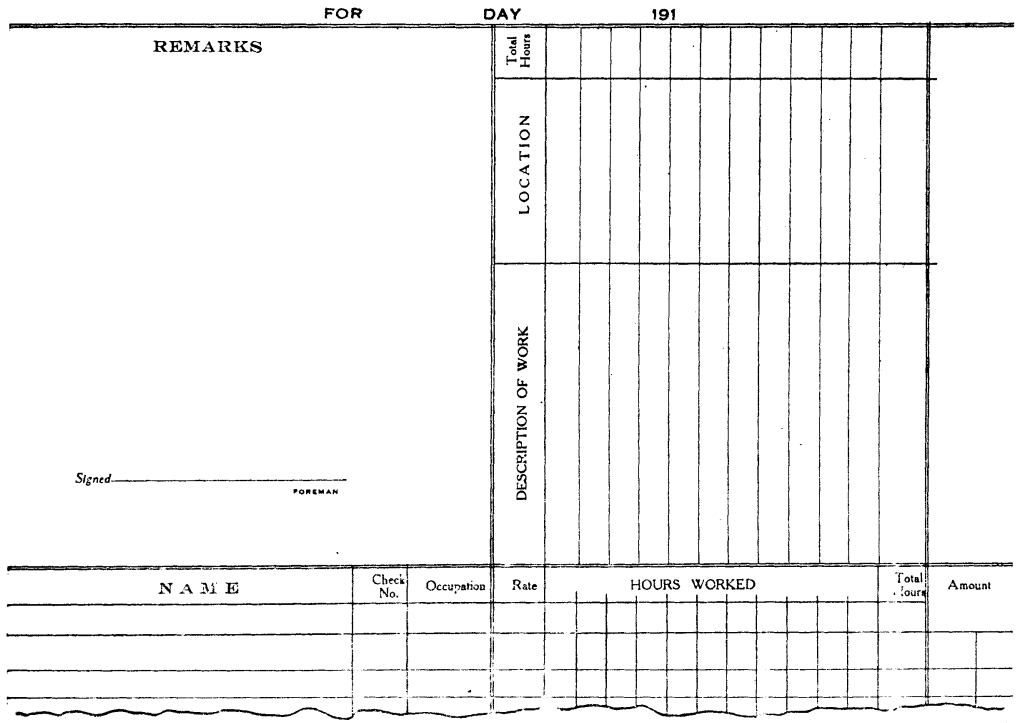

FIG. 1

of multiple-unit trains, and the pantagraph collector is watched during the entire run over the road and any defects or any wires off center are noted.

At specified times each month the circuit breakers on the sectionalizing bridges are inspected and repairs made if necessary. Any defects or other matters of irregular appearance are immediately reported and the night gang is lined up to make the stated repairs or adjustments.

The night crew also makes specified inspections on the line repairing where necessary, but generally the entire time of 
the night crew, which is actually only about $4 \frac{1}{2}$ to 5 hours, due to traffic conditions, is taken up with regular maintenance work, which has been previously lined up for it.

The day crew reports its work on a regular form, as shown in Fig. 1, and the night crew also uses the same form, and in addition, turns in a work train report, as shown in Fig. 2, which includes the movement of the work train, as well as specifying what work has been done and what the general condition of the line is in when the crew returns from the road.

Results of Inspection

As already stated, a constant inspection has rapidly reduced the slight difficulties which arose from time to time after the road was first put into operation.

For example: For the year ending December 1913, a total of 37 pantagraph collectors were broken, out of 91,250 pantagraph trips made during the year. For the year ending December 1914, there were 19 pantagraph collectors broken out of 94,900 pantagraph trips made during the year; and for the three months ending March 1915, four pantagraph collectors were broken out of 23,400 pantagraph trips made during
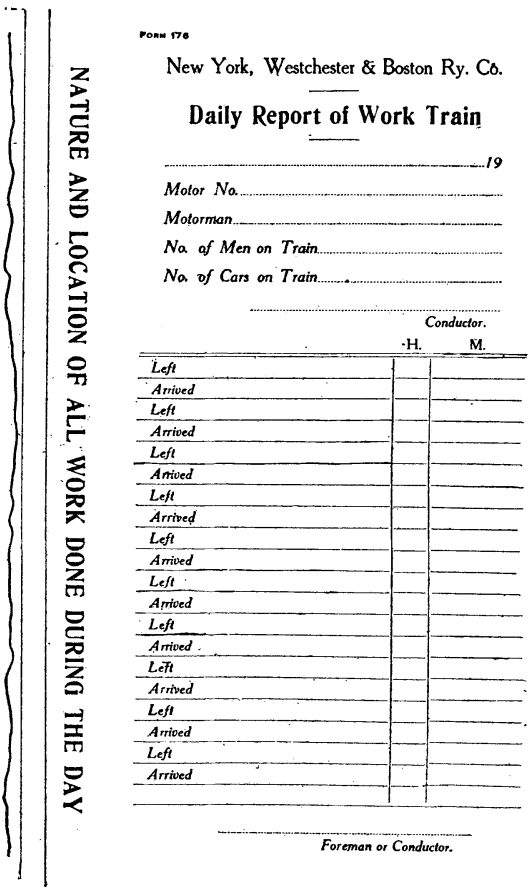

FIG. 2 the three months; making 2,466 pantagraph trips per one pantagraph failure in $1913 ; 4,994$ pantagraph trips per one pantagraph failure in 1914; and 5,850 pantagraph trips per one pantagraph failure for the three months ending March 1915.

\section{Operating Efficiency}

In 1913 there were 27,927 car miles operated per one pantagraph failure, in 1914 there were 55,503 car miles operated per one pantagraph failure, and for the three months ending March 1915 , there were 64,799 car miles operated per one pantagraph failure. 
The usual cause for broken pantagraphs is due to wire off center, low joints on running rails on curves, overhead frog on deflector out of adjustment and loose sleeves on contact wire.

The following tables give the total delays caused by broken pantagraph collectors and power troubles, shown in comparison with the train miles operated, with the typical causes given for the delays.

\begin{tabular}{|c|c|c|c|c|c|c|}
\hline \multirow[t]{2}{*}{ Year } & \multirow[t]{2}{*}{ Month } & \multirow[t]{2}{*}{ Train miles } & \multicolumn{2}{|c|}{ Power trouble } & \multicolumn{2}{|c|}{$\begin{array}{l}\text { Pantagraph and contact } \\
\text { wire trouble }\end{array}$} \\
\hline & & & Delays & Minutes & Delays & Minutes \\
\hline 1913 & Jany. & $73,939.07$ & 29 & 584 & 1 & 5 \\
\hline “ & Feby. & $68,323.64$ & 13 & 79 & 3 & 20 \\
\hline “ & March & $74,206.19$ & 1 & 6 & 0 & 0 \\
\hline “ & April & $71,684.33$ & 38 & 243 & 1 & 15 \\
\hline “ & May & $74,103.24$ & 25 & 382 & 1 & 5 \\
\hline “ & June & $72,925.33$ & 13 & 114 & 6 & 40 \\
\hline “ & July & $75,033.20$ & 29 & 187 & 2 & 22 \\
\hline " & August & $74,674.88$ & 14 & 101 & 1 & 5 \\
\hline “ & Sept. & $72,223.94$ & 9 & 92 & 1 & 10 \\
\hline " & October & $74,644.30$ & 9 & 62 & 1 & 7 \\
\hline$"$ & Nov. & $72,160.28$ & 15 & 242 & 0 & 0 \\
\hline \multirow[t]{2}{*}{$"$} & Dec. & $75,386.58$ & 15 & 78 & 0 & 0 \\
\hline & & $879,304.98$ & 210 & 2170 & 17 & 129 \\
\hline
\end{tabular}

\begin{tabular}{|c|c|c|c|c|c|c|}
\hline \multirow[t]{2}{*}{ Year } & \multirow[t]{2}{*}{ Month } & \multirow[t]{2}{*}{ Train miles } & \multicolumn{2}{|c|}{ Power trouble } & \multicolumn{2}{|c|}{$\begin{array}{l}\text { Pantagraph and contact } \\
\text { wire trouble }\end{array}$} \\
\hline & & & Delays & Minutes & Delays & Minutes \\
\hline \multirow{12}{*}{ 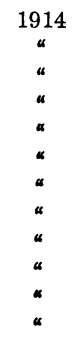 } & Jany. & $75,330.00$ & 16 & 227 & 4 & 25 \\
\hline & Feby. & $67,088.08$ & 20 & 398 & 1 & 5 \\
\hline & March & $74,634.69$ & 2 & 2 & 0 & 0 \\
\hline & April & $71,044.61$ & 1 & 5 & 0 & 0 \\
\hline & May & $74,160.23$ & 8 & 434 & 1 & 7 \\
\hline & June & $72,312.00$ & 8 & 33 & 4 & 51 \\
\hline & July & $75,387.60$ & 3 & 14 & 0 & 0 \\
\hline & August & $74,406.68$ & 19 & 927 & 0 & 0 \\
\hline & Sept. & $72,241.02$ & 0 & 0 & 0 & 0 \\
\hline & October & $74,659.04$ & 0 & 0 & 0 & 0 \\
\hline & Nov. & $72,216.96$ & 9 & 109 & 2 & 12 \\
\hline & Dec. & $74,639.48$ & 11 & 107 & 3 & 17 \\
\hline \multirow{5}{*}{$\begin{array}{c}1915 \\
\star \\
\text { “ }\end{array}$} & \multirow{5}{*}{$\begin{array}{l}\text { Jany. } \\
\text { Feby. } \\
\text { March }\end{array}$} & $878,120.39$ & 97 & 2256 & 15 & 117 \\
\hline & & $74,627.36$ & 0 & 0 & 0 & 0 \\
\hline & & $67,388.36$ & 0 & 0 & 1 & 2 \\
\hline & & $74,654.61$ & 0 & 0 & 0 & 0 \\
\hline & & $216,670.33$ & 0 & 0 & 1 & 2 \\
\hline
\end{tabular}


Typical Causes for Delays Caused By:

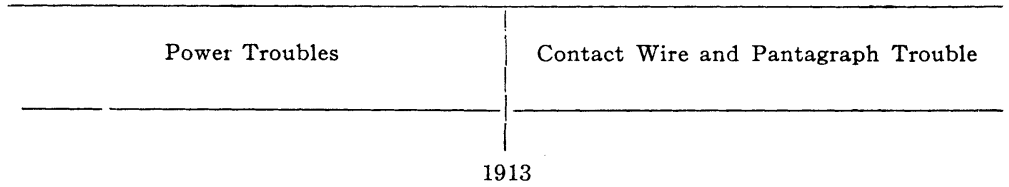

Jan. 2 : Power off three minutes, due to|Jan. 4 : Contact dead end broken by undiscovered grounds pantagraph

Jan. 4 : Grounds due to broken pantagraph

Jan. 9 : Power off three contact lines, four Jan. 17 : Short circuit of pantagraph minutes, due to undiscovered insulator, due to foreign grounds

Jan. 21 : Short circuit of pantagraph insulator, due to limb of tree.

February

Feb. $10: \frac{5}{8}$ messenger grounding against lower cord of highway bridge.

Feb. 14 : Broken pantagraph on crossover, on account of deflector.

March

May

July

| March 5 : Broken pantagraph, due to train running past deadend in storage yard.

March 11 : Due to car in storage yard bridging current on line to ground, by raising two panta-

graphs.

March 15 : Broken pantagraph, due to pantagraph sprocket chain breaking.

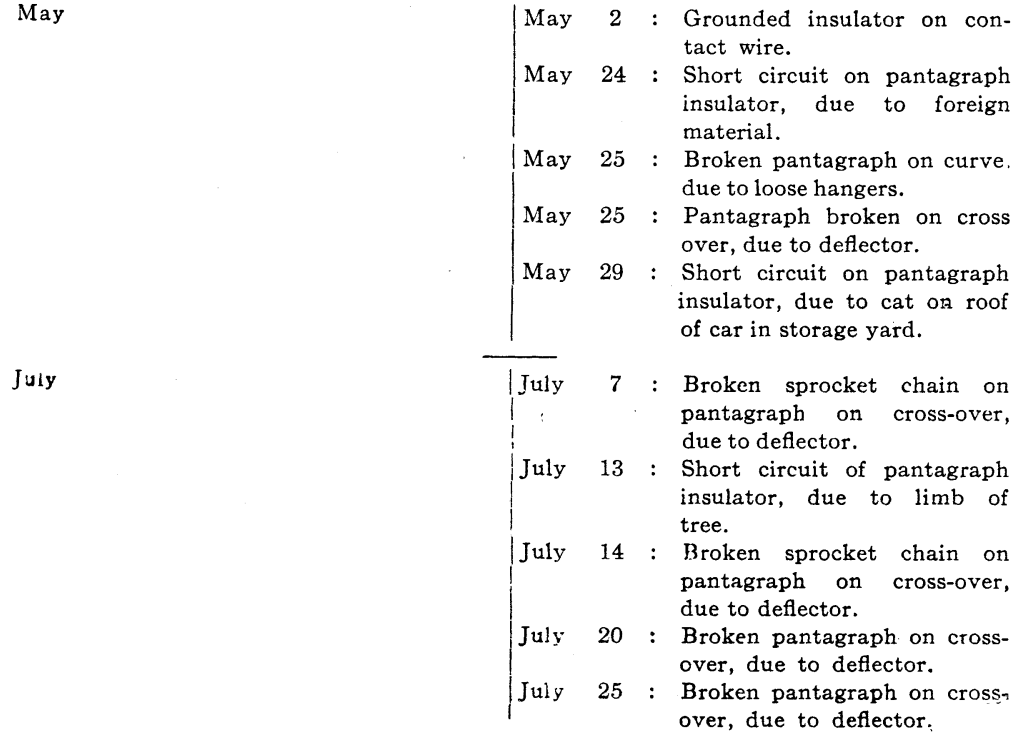




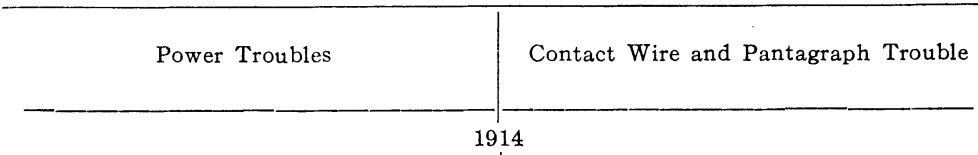

Feb. 16 : Power off five contact lines, five $\mid$ Feb. 17 : Grounded line switch on car minutes, due to undiscovered Feb. 18 : Due to grounded transformer grounds. on car.

March 1: Grounded feeders, due to pro- March 20 : Grounded contact wires, due tection screens being broken down by snow. to ice connecting between contact wire and highway bridge.

May

August

February

\begin{tabular}{|c|c|c|c|}
\hline May & & & $\begin{array}{l}\text { 2nd: Grounded insulator on } \\
\text { contact wire. }\end{array}$ \\
\hline May & 6 & : & $\begin{array}{l}\text { Arc drawn by pantagraph } \\
\text { grounding on messenger. }\end{array}$ \\
\hline May & 18 & : & $\begin{array}{l}\text { Broken pantagraphs on two } \\
\text { cars at cross-over, due to } \\
\text { deflector. }\end{array}$ \\
\hline May & 20 & : & $\begin{array}{l}\text { Due to arc drawn by panta- } \\
\text { graph grounding on catenary } \\
\text { bridge. }\end{array}$ \\
\hline May & 27 & : & $\begin{array}{l}\text { Broken pantagraph, due to } \\
\text { pantagraph leaving wire on } \\
\text { curve. }\end{array}$ \\
\hline May & 28 & : & $\begin{array}{l}\text { Grounded pantagraph insu- } \\
\text { lator due to branch of tree. }\end{array}$ \\
\hline Aug. & 3 & : & $\begin{array}{l}\text { Broken pantagraph breakıng } \\
\text { insulator on curve. }\end{array}$ \\
\hline Aug. & 23 & : & $\begin{array}{l}\text { Due to grounded pantagraph, } \\
\text { caused by bird on roof of car. }\end{array}$ \\
\hline Aug. & 29 & : & $\begin{array}{l}\text { Broken insulator on contact } \\
\text { wire. }\end{array}$ \\
\hline
\end{tabular}

Feb. 3 : Due to arc drawn by pantagraph, grounding messenger.

Also, the graphical charts shown in Figs. 3A, B, C, D, represent the total minutes delay, divided between power trouble and contact wire and pantagraph trouble.

\section{INSULATION}

All told, on the 54.26 miles of track, there are the following numbers of insulators:

On the 11,000-volt lines, there are 2,557 pin insulators, 1,949 safety strain insulators, 164 wood strain insulators, 2,004 catenary suspension insulators and 87 dead-end strain insulators; on the 2200-volt signal lines there are 1,368 pin insulators and 971 safety strain insulators; making a total of 9,100 insulators.

Out of the total number of 2,339 insulators carrying the signal 
transmission lines there have been no insulator failures after approximately three years' operation, and out of the 6,761 insulators carrying the 11,000 -volt lines there have been the following failures:

In 1913: One insulator failure on contact lines.

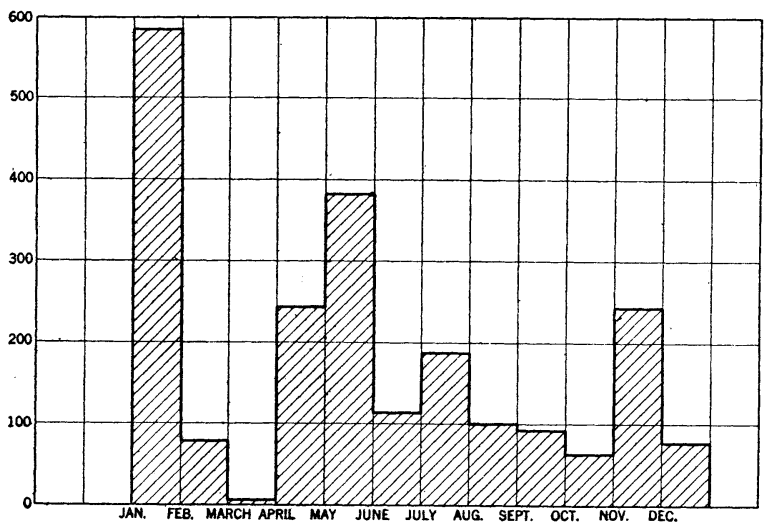

Fig. 3A-Total Minutes Delay due to Power Trouble, 1913

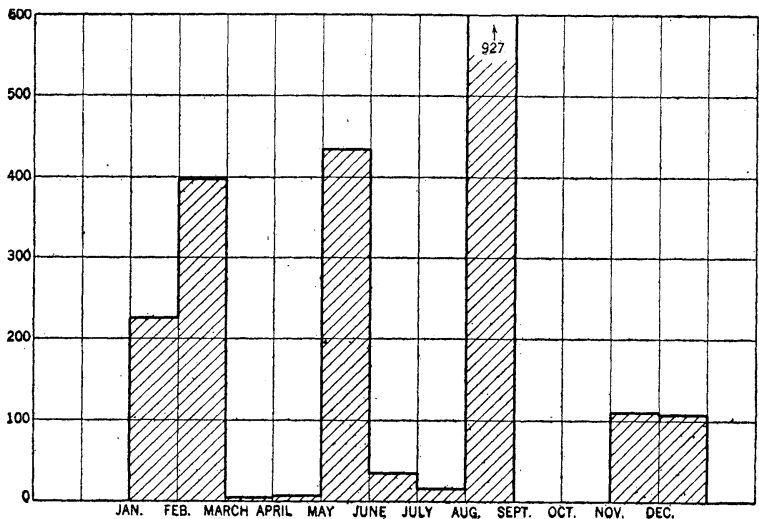

Fig. 3B-Total Minutes Delay due to Power Trouble, 1914

In 1914: Seven insulator failures, six of which were on contact lines and one on the transmission line.

In 1915: There has been one insulator failure on the transmission lines.

This makes approximately 100 per cent insulation in 1913, a little better than 99 per cent insulation in 1914 and approximately 100 per cent so far in 1915 . 
WEAR

The following table shows the mileage obtained by pantagraph shoes and it is to be noted also, that the actual wear on the contact wire from the rubbing effect of the shoe has amounted

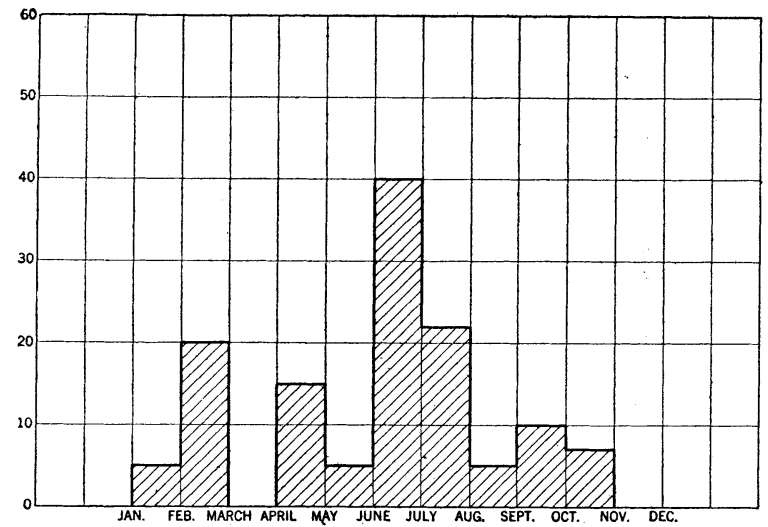

Fig. 3c-Total Minutes Delay due to Pantagraph and Contact Wire Trouble, 1913

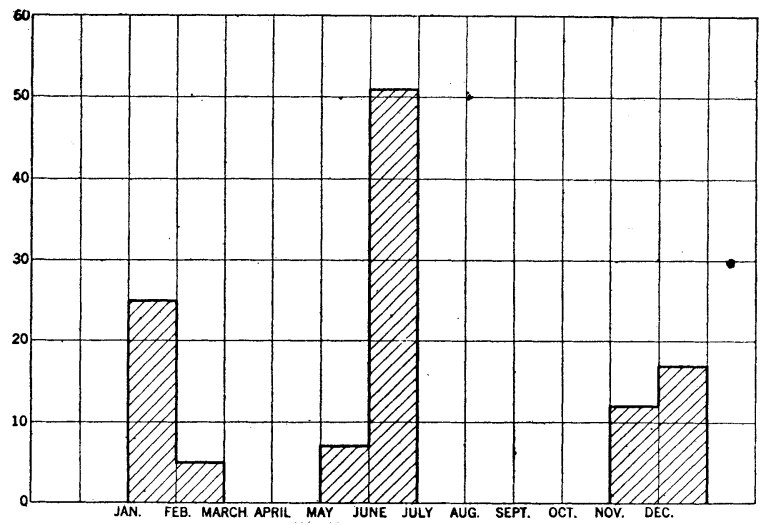

Fig. 3D-Total Minutes Delay due to Pantagraph and Contact Wire Trouble, 1914

to about $\frac{1}{8}$ in. flat surface on the under side of the grooved steel contact wire. This wear has been uniform over the entire line and there seems to be no indication of more wear on the low wire than on the high wire, and the wear on curves, also, is about the same, so that at the rate of wear as noted at the present 
time, it should be not necessary to renew the steel trolley wire for six or seven years, at least, from the initial installation.

\begin{tabular}{|c|c|c|c|}
\hline Year & Month & $\begin{array}{l}\text { Fanta- } \\
\text { graphs } \\
\text { broken }\end{array}$ & Mileage \\
\hline 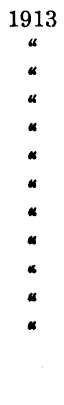 & $\begin{array}{l}\text { January } \\
\text { February } \\
\text { March } \\
\text { April } \\
\text { May } \\
\text { June } \\
\text { July } \\
\text { August } \\
\text { September } \\
\text { October } \\
\text { November } \\
\text { December }\end{array}$ & $\begin{array}{c}2 \\
5 \\
3 \\
6 \\
2 \\
6 \\
5 \\
6 \\
0 \\
0 \\
1 \\
1 \\
37\end{array}$ & $\begin{array}{r}840 \\
1049 \\
1046 \\
1109 \\
1320 \\
1357 \\
1425 \\
1866 \\
2379 \\
2667 \\
1775 \\
1669\end{array}$ \\
\hline
\end{tabular}

\begin{tabular}{|c|c|c|c|}
\hline Year & Month & $\begin{array}{l}\text { Panta- } \\
\text { graphs } \\
\text { broken }\end{array}$ & Mileage \\
\hline $\begin{array}{c}1914 \\
a \\
\alpha \\
\alpha \\
\alpha \\
\alpha \\
\text { a } \\
\alpha \\
\alpha \\
\text { a } \\
\text { a }\end{array}$ & $\begin{array}{l}\text { January } \\
\text { February } \\
\text { March } \\
\text { April } \\
\text { May } \\
\text { June } \\
\text { July } \\
\text { August } \\
\text { September } \\
\text { October } \\
\text { November } \\
\text { December }\end{array}$ & $\begin{array}{l}4 \\
1 \\
0 \\
0 \\
3 \\
2 \\
2 \\
2 \\
1 \\
0 \\
2 \\
2\end{array}$ & $\begin{array}{l}1330 \\
1144 \\
1053 \\
1333 \\
1470 \\
1885 \\
2098 \\
2127 \\
2036 \\
1541 \\
1224 \\
1145\end{array}$ \\
\hline $\begin{array}{c}1915 \\
\star\end{array}$ & $\begin{array}{l}\text { January } \\
\text { February } \\
\text { March }\end{array}$ & $\begin{array}{r}19 \\
1 \\
1 \\
2 \\
4\end{array}$ & $\begin{array}{l}1210 \\
1197 \\
1091\end{array}$ \\
\hline
\end{tabular}

It is to be noted in the above table that the mileage obtained by pantagraph shoes decreases in the winter months and increases in the summer months. This is due to the fact that it is necessary to raise the tension on the upward motion of the pantagraph in the cold weather, on account of the slight raising in the contact wire, caused by contraction. 


\section{Rules and Regulations}

A book of rules has been issued for the instruction and guidance of employes in the electrical department, as well as the other departments. Particular emphasis is laid on rules of safety and it is made clear to all the men engaged in high-tension work that great care must be taken to avoid coming in contact with any electrical equipment. The men are carefully examined in all the rules, as well as to their knowledge of general high-tension work. The following are some of the rules which the men are required to obey under penalty of dismissal:

All high-tension feeders, catenary wires, busses, oil switches and other high-tension apparatus, shall be considered alive at all times and shall be considered dead only when specified by the proper authority.

Employes whose duties require them to work in the vicinity of or in direct connection with, any high-tension apparatus, trolley wires, feeders or busses, are cautioned against the dangers involved and are forbidden to engage in such work unless duly authorized and properly protected.

No attempt shall be made to work on any of the 11,000 -volt system, namely, feeders, trolley wires, anchor bridge apparatus, bomb fuses, lightning transformers and high-tension telephone lines, while it is alive.

If at any time there is doubt about the condition of any piece of $\mathbf{1 1 , 0 0 0}$ volt apparatus, no work is to be attempted. In case of feeders or trolley wires, which are always to be considered alive, no work is to be attempted until they are properly "grounded" in the immediate vicinity of point where men are to work.

A proper ground will be established by connecting, by means of a clamp, one end of a piece of stranded copper cable, not less than No. 0000 in size, to any iron work known to be connected to the running rails of the railroad and the other end connected to the feeder or trolley wire by a second clamp, this clamp to be operated by means of a pole at a distance of not less than six feet $\left(6^{\prime}\right)$ from below the feeder or trolley. The "ground" end of the wire must be applied first while grounding a feeder or trolley, and removed last while clearing or removing ground from feeder or trolley.

No 11,000-volt switch will be operated except by means of dry wood poles provided for the purpose. Operator's hands must never be placed at a distance less than six feet from live end of pole.

No work shall be attempted on any 11,000-volt automatic circuit breaker or 11,000-volt transformers, without first disconnecting it from power supply, by means of disconnecting switches provided with the apparatus.

No work shall be attempted on one or more transformers which are connected together for three phase operation without first disconnecting all transformers of the group from power supply by means of disconnecting switches provided for the purpose. 
No unauthorized person shall be allowed in the vicinity of unprotected apparatus or allowed to assist workmen engaged on 11,000 -volt apparatus.

Also, the following instructions are issued to all employees of the road, so that they may be properly guided and instructed with reference to the electrical equipment.

All employes, except those who are properly authorized, are forbidden to enter upon or climb any catenary bridge or pole, signal or anchor bridge.

All employes, except those who are properly authorized, are forbidden to go within six feet of any high-tension apparatus, feeders or busses.

All employes of this Company, except those who are properly authorized, are forbidden to climb upon the roof or superstructure of any car, locomotive or other equipment.

As the entire handling of the power on the line is done by one set of men, namely, the load despatchers, who have entire jurisdiction over the cutting in and cutting out of the various high-tension lines, a special set of instructions has been issued for this purpose. These instructions cover the method of opening and closing high-tension circuit breakers, etc. Portions of these instructions are shown below.

\section{InSTRUCTIONS TO LOAD DESPATChERS}

If, for any reason, a track wire is desired cut out, Load Despatcher will first take up the matter with the Train Despatcher and get his $\mathrm{O}$. K. by a written message transmitted by telephone before the track wire is cut out, in order that there will be no power shut off while a train is in this section.

If a ground occurs on the line, Load Despatcher will immediately get in touch with Train Despatcher advising him just what tracks are out, and if possible, in what particular section ground occurred. Train Despatcher will get in touch with all trains in this section and advise Load Despatcher if any train in the said section has caused ground. Load Despatcher, upon receiving information from Train Despatcher that he has no train in this section which reports ground, will throw power on line a second time. If power fails to hold on second trial, Load Despatcher will not throw power on again until definite information is received from some definite source, either through Train Despatcher or representative of the Maintenance Department, that line is clear; this information must be sent in the form of a phonogram. If a ground occurs on any track or feeder causing circuit breaker to open, a period of at least five minutes must elapse before power is cut in, on said track or feeder, unless positive information is received as to the cause of interruption.

Orders to Towermen, Anchor Bridge Operators and Signal Maintainers, instructing that circuit breakers or switches be opened or closed, must 
be done by a written order stating specifically what this operation is to be. The men instructed to carry out the orders will reply when same is complete by written message.

If any circuit breakers open automatically on a ground or for any other reason, the Towerman at the point where the circuit breaker has opened will inform the Load Despatcher which breaker opened.

When any men are working on the line that has been cut out, power

ronu 170

NEW YORK, WESTCHESTER \& BOSTON RAILWAY CO.

FAILURE REPORT CATENARY SYSTEM

\begin{tabular}{|c|c|c|c|c|c|c|c|}
\hline \multicolumn{3}{|c|}{ POWER OFF } & \multirow{2}{*}{$\begin{array}{l}\text { DESCRIP TION } \\
\text { OF FAILURE }\end{array}$} & \multirow{2}{*}{$\begin{array}{c}T_{\text {rain }} \\
\text { No. }\end{array}$} & \multirow{2}{*}{ 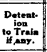 } & \multirow{2}{*}{ LOCATION } & \multirow{2}{*}{ CAUSE OFFAILURE } \\
\hline From & $\mathrm{T}_{0}$ & Tliomod & & & & & \\
\hline & & & & & & & \\
\hline & & & & & & & \\
\hline & & & & & & & \\
\hline
\end{tabular}

FIG. 4

is not to be thrown back until the foreman in charge of the line gang has reported by written message to the Load Despatcher that his men are entirely clear and all grounds have been removed from the line and Train Despatcher notified.

If at any time pantagraphs are broken on any of the trains and the trouble has not been ascertained, no train should be run through this

\begin{tabular}{|c|c|c|c|c|c|c|}
\hline \multicolumn{3}{|c|}{ Maintenance Dept. } & \multicolumn{2}{|l|}{ Date- } & \multirow[b]{2}{*}{ 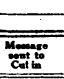 } & \multirow{2}{*}{ 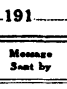 } \\
\hline symBoL & LOCATION & ent & 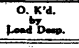 & sontis & & \\
\hline & & $\mathrm{m}$ & & & w. & \\
\hline & & m. & n. & & is & \\
\hline & & м. & м. & & m. & \\
\hline & & m. & s. & & m. & \\
\hline & & м. & n & & м. & \\
\hline & & n. & m. & & 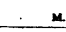 & \\
\hline & & m. & is. & & w. & \\
\hline
\end{tabular}

FIG. 5

section until the trouble has been ascertained, and it is found safe to run trains by the point where the pantagraph was broken.

Instructions to Towermen in Operating Switchboards Controlling High-Tension Power

No circuit breakers or switches shall be closed without written orders from the Load Despatcher.

If any circuit breaker opens automatically on a ground, overload 


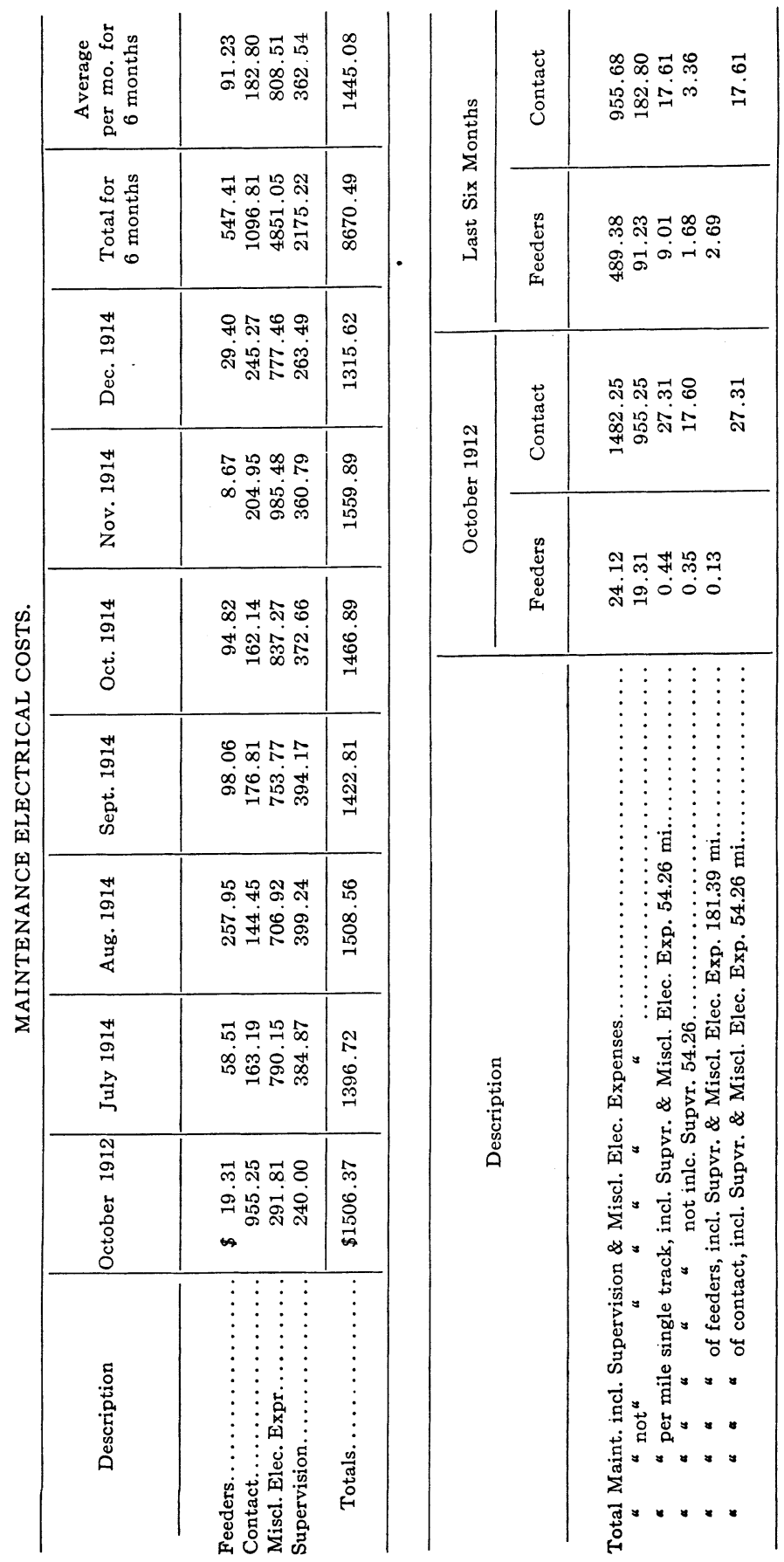


or for any other reason, he must immediately get in communication by telephone with Load Despatcher and inform him in detail what has taken place. It is especially important to note when any circuit breaker opens it is not to be closed again without an order from Load Despatcher.

\section{Maintenance Records and Costs}

A record is kept of all the failures on the electrical system and is shown each day on a blank filled out by the load despatcher and checked by the maintenance forces, and is shown in Fig. 4.

Records are also kept of all lines worked on by the electrical forces showing just what lines were taken out of service. This report is filled in on a blank, as shown in Fig. 5.

The table on the opposite page shows the various costs of maintenance of the overhead contact system, and for comparison the figures are shown for October 1912, shortly after the system was put into operation, and an average for the six months ending December 1914. Included in the cost per unit is the cost of miscellaneous electric line expenses, which includes sectionalizing bridges, sectionalizing equipment, time of men while on emergency duty, work train, and in fact, all charges which cannot be placed actually against feeders and contact.

As a matter of comparison, the cost of electrical maintenance is given per car mile for July 1914 and December 1914, as follows:

Total maintenance per car mile, July $1914 \ldots \ldots \$ .0156$

Total maintenance per car mile, December $1914 \$ .0142$

The above figures include supervision, transmission and contact system, miscellaneous electric line expenses, work train, etc.

It will be seen in reviewing the above paragraphs that the various difficulties, none of which were serious, and the costs involved in overcoming the same, have decreased as time progresses, and we would, therefore, assume that the inverted peak of the triangle has not as yet been reached. 